\title{
ARE MEN MORE INNOVATIVE AND AGGRESSIVE IN BUSINESS? CASE STUDY FROM THE CZECH REPUBLIC
}

\author{
Přemysl BARTO $\check{S}^{18}$ Aleksandr KLJUČNIKOV, ${ }^{19}$ Boris POPESKO, ${ }^{20}$ Jiří $^{2}$ \\ $M A C H A ́ C \check{E} K^{21}$
}

\begin{abstract}
SMEs make a major contribution to the growth and employment in the EU. In today's fierce competition in the market economic activities the SMEs had gradually developed into a major force for national economic and social development in every country of world. The aim of this article is to examine the approach to innovativeness and competitive aggressiveness between males and females in the segment of small and medium-sized enterprises. Based on the results of the questionnaire which was conducted in May 2015 in the Czech Republic we tried to test four hypotheses on the relationship between the gender of entrepreneurs of SMEs and their attitude to innovativeness and competitive aggressiveness. The results of our research have pointed out some differences between genders. Men-entrepreneurs who do business in the segment of SMEs in the Czech Republic are slightly more innovative and are significantly more aggressive in regard to competitors than women, as they apply aggressive approach and their companies are perceived as aggressive.
\end{abstract}

\section{KEY WORDS}

Small and medium-sized enterprises, gender, innovativeness, competitive aggressiveness

\section{JEL CLASSIFICATION}

GL26, R11

\section{INTRODUCTION}

The issue of business risks of the small and medium enterprises (SME) currently represents contemporary area of theoretical research and practical applications.

\footnotetext{
${ }^{18}$ Correspondence address: Ing. Přemysl Bartoš, PhD., Department of Enterprise Economics, Faculty of Management and Economics, Tomas Bata University in Zlin, Mostní 5139, 76001 Zlin, Czech Republic; email: p.bartos@fame.utb.cz

${ }^{19}$ Correspondenceaddress: Ing. Aleksandr Ključnikov, PhD., Department of Managerial Economics, University of Business and Law, Michálkovická 1810/181, 71000 Ostrava, Czech Republic, email: kliuchnikov@ gmail.com

${ }^{20}$ Correspondence address: assoc. prof. Ing. Boris Popesko, PhD., Department of Enterprise Economics, Faculty of Management and Economics, Tomas Bata University in Zlin, Mostní 5139, 76001 Zlin, Czech Republic; email: popesko@fame.utb.cz

${ }^{21}$ Correspondence address: Ing. Jiří Macháček, Department of Regional Development, Public Sector Administration and Law, Faculty of Management and Economics, Tomas Bata University in Zlin, Mostní 5139, 76001 Zlin, Czech Republic; email: machacek@fame.utb.cz
} 
Small and medium-sized enterprises (SMEs) in general and the establishment of new enterprises in particular play an important role in creation and keeping of a functioning market economy, especially as a means of stimulating competition, creating jobs and promotion of the economic recovery (Kessler, 2007). SMEs are considered to be important generators of economic development, which contribute to addressing the economic, political and social problems of the state. They include the vast majority of private sector enterprises and ensure more than $50 \%$ of employment and manage economic growth. On the other hand, due to their size, they often face both internal (lack of management skills) and external (unfavorable market conditions and institutional settings) obstacles that may hinder their further growth. (Hessels, Parker, 2013)

Our article is devoted to the differences in approaches of men and women in the field of innovation activities and aggressiveness to competitors.

\section{THEORETICAL BACKGROUND}

Entrepreneurial orientation is a key element for the success of SMEs (Brockman, Jones, andBecherer, 2012; Boso, Story, and Cadogan, 2013). To behave entrepreneurially means the company should engage in these strategic activities- innovativeness, competitive aggressiveness, proactiveness, risk taking, autonomy. (Anderson and Eshima, 2013; Sidik, 2012)

According to Gudmundson and Lechner (2014) entrepreneurial orientation has a positive effect on the firm performance with both cost leadership and differentiation strategies. Their result shows that innovativeness and autonomy has a positive relationship with product differentiation strategy whereas risk taking and competitive aggressiveness has a negative relationship with innovativeness, but no significant relationship was found with proactiveness. The findings of Moreno and Casillas (2008) showed that higher entrepreneurial orientation favors the strategies through product and process innovation, thus entrepreneurial orientation will have impact on the firm innovations strategies that can support launching new products rather than entering to new market segments.

Kraus (2013) states that there is a significant relationship between firm performance and entrepreneurial orientation of the entrepreneur. More experienced entrepreneurs are more inclining to risks, more innovative and proactive within their organization. Similarly Blackburn, Hart, and Wainwright (2013) found out that small business performance is largely depended on the business strategies, age of the business, size of the business and entrepreneurial characteristics and entrepreneurs with high risk tolerance, innovativeness and willingness to use new technologies are more successful in generating profits for the firm.

Innovativeness reflects the tendency of companies to promote new ideas, innovations, experiments and creative processes that can result in new products, services or technological processes. According to Lasagni (2012) the innovation performance is higher in SMEs that are proactive in strengthening their relationships with innovative suppliers, users, and customers. Martínez-Roman and Romero (2013) have found out that SMEs that have introduced their substantial product innovations are led by the businessmen with a large internal motivation. Boyer and Blazy (2014) examined the determinants of survival of non-innovative and innovative enterprises; the survival of these companies is associated with personality characteristics, such as gender, age, association with a national minority, professional experience and financial resources.

Competitive aggressiveness perceived as a further element of business orientation is according to Lumpkin and Dess (1996) related to the companies' qualities and direct and intensive challenge of the competitors in order to enter the market or to improve the markets' position, i.e. to fulfill the role 
of rivals in the market. It is typical, for the company to react in a way which may be considered as a direct confrontation, for example when the company enters the market dominated by another competitor or it behaves reactively for example when the company reduces the price in response to the competitor appeal.

Soininen, Puumalaiene, Sjogren, and Syrja (2012) analysed the role of entrepreneurial orientation in global economic crisis. By using a sample of 194 SMEs in the Finnish market they have found that entrepreneurial orientation namely innovativeness and pro-activeness indeed played a crisis mitigating role in the crisis period. They found a negative effect of risk taking and financial as well as operational performance. It means that those firms that are more risky have suffered more in the financial crisis period than the firms those are risk averse. The profitability and liquidity measures of risk taking also show that during the financial crisis their profitability and liquidity reduced a lot for the high risk taking firms. Nevertheless, innovativeness and pro-activeness positively affected the firm's assets and revenues, but they did not find any evidence for the liquidity and profitability. The results provide support for firms with entrepreneurial orientation, because innovative and proactive firms can launch new product and services for their customer to maintain the operational balance and the financial stability. More risk taking firms are uncertain and they are financing to utilize the leverage. On the other hand, innovative and pro-active firms are taking initiatives to utilize their own resources that can create a completive edge over their rivals in terms of resource utilization. Thus, firms with more EO can have more smoothed growth than firms with lower EO, due to balancing nature of risk taking and more innovativeness and pro-activeness.

Examining of identical and different features between the two genders belongs to the important areas addressed by several authors. According to Mueller and Dato-on (2010) women play an important role in the growth of businesses worldwide, but there is still a considerable difference in participation rates. Similarly International Finance Corporation (2013) states that female entrepreneurs greatly contribute to the formal economy. An estimated 31 to 38 percent of formal SMEs in developing economies are fully or partially owned by women.

Gender influences the extent of participation in business and an approach to risk assessment. Studies show that there are a lot of differences between male and female entrepreneurs. Understanding of success is one of the examples. Women understand success as the ability to take control of their destiny, build relationships with prospective clients and do things that fulfil them, while men define success as achieving the objectives. In this context Millian, Congregado, Roman, Van Praag, and Van Stel (2014) statethatmen entrepreneurs can have higher incomes than women entrepreneurs. Moreover, there is a chance that women can leave the venture due to family issues and or age.

According to Goktan and Gupta (2015) individual entrepreneurial orientation is higher among men rather than women. They find that men are much more innovative, risk taking incentives and proactive in entrepreneurship development. At the same time they enhance that people having masculine values are competitive, aggressive and they are motivated to gain wealth, through business development.

Langowitz and Minniti (2007) found out that women are more risk averse than men, and that higher riskiness does not prevent men from starting the business. This finding confirm Diaz-Garcia and Jimenez-Moreno (2010) and at the same time they state that females are more innovative and objective in achieving task and men are likely have a thought about the intention to create a firm rather than doing it in practically. Also Runyan, Huddleston, and Swinney (2006) found out that females are more innovative than their males counterpart, but on the other hand in risk taking females scored more than the males and there were no significant differences found in proactiveness. Compared to Ayub, Razzaq, Aslam, and Iftekhar (2013) their results show that 
women have lower innovativeness and autonomy, but are more proactive and risk averse and less aggressive than men. The research by Kozubíková and Bartos (2015) and Kozubíková, Belas, Bilan, and Bartos (2015) provides interesting results in this context.

Women-owned SMEs face the same challenges as every other SME. However, these challenges are usually amplified, and/or harder to overcome. And these seem to reflect the size of women-owned enterprises: they are mostly very small and small firms. Is this by their choice, or are women entrepreneurs specifically constrained? In terms of access to finance there is evidence that women entrepreneurs have a disadvantage compared to their male counterparts. Access to finance by women-owned enterprises is constrained by legal and regulatory environment, firm specific/ownerspecific characteristics (e.g. education, training, size of firm, etc.), and cultural barriers, which may impact women entrepreneurs disproportionately, in addition to other barriers to access faced by SMEs in general. (International Finance Corporation, 2013)

Global Markets Institute (2014) submits similar conclusions. Women-owned SMEs face barriers to entry and the growth of business that include access to education and training, legal and cultural barriers and infrastructure-related challenges. Access to finance is typically identified as a critical constraint. While financing is almost always a challenge for SMEs, the difficulties are often intensified by gender-related factors, including women's lack of collateral, weak property rights and discriminatory regulations, laws and customs.

In this context we emphasize that access to external financing significantly determines the success of innovation policy of the company.

Inspirational conclusions can be found in the studies by Envick and Lim (2011). Authors state that there is a significant difference in risk taking among the male and female respondents. The potential male entrepreneurs are ready to accept more risk than the female entrepreneurs, it is suggested that females are more risk adverse than their male counterparts. It is also found that, in the USA and Korea males are more independent decision makers than females, however, the result is less significant for Malaysia and Fiji. Males are more confident in their decision making than females in all the four countries surveyed. It is also noticeable that females are less aggressive in the competitiveness rather than males. Whereas males prefer to be more aggressive when they find any competitive opportunity to enter the market. Females are not interested in the growth of their firms, they are happy with their stable condition. However, females are found to be more innovative than males, which is one of their advantages in the formation of new enterprise in comparison to males.

\section{OBJECTIVES, METHODOLOGY AND DATA}

The aim of this article is to examine the approach to innovativeness and competitive aggressiveness between males and females in the segment of small and medium-sized enterprises (SMEs).

The research of the business environment was prepared in 2014 and was conducted in the Czech Republic in 2015. The companies were chosen from Albertina database. The total number of 1,650 randomly selected firms was addressed by e-mail of telephone to fill in the questionnaire placed at website https://docs.google.com/forms/d/1U9coaC5JRL0N2QOOO6Xb8j3mnaZXdSM47Kugt4EDGFo/vie wform? usp=send form. The data was provided by 1,141 owners of SMEs in 14 regions of the Czech Republic. The questionnaire consisted of 52 questions. In this context, in the first nine questions we devoted to the analysis of the structure of the respondents in relation to their education, gender, age, the residency and size of a firm, the length and area of conducting business, motives for starting a business and the most important characteristics of entrepreneur. The rest of 
questions were scale questions of the scale of 1 to 5 ( 1 - fully agree, 2 - agree, 3 - no position, 4 disagree, 5 - completely disagree) focused on the five elements of entrepreneurial orientation.

The structure of the sample according to the business area was as follows: trade companies (33\%), manufacturing companies (23\%), construction companies $(14 \%)$, transport companies $(6 \%)$ and agricultural firms (3\%). The largest portion of companies operated in other sectors (39\%).In accordance to the length of doing business from the total number of 1,141 companies $62 \%$ of them were doing business for more than 10 years, $21 \%$ of them between 1 and 5 years, and $17 \%$ of them between 5 and 10 years. It can be said that the owners of the companies were quite experienced entrepreneurs. $65 \%$ of firms were micro-enterprises, $27 \%$ were small enterprises and $8 \%$ were medium-sized enterprises. Most of the entrepreneurs in the sample, concretely $48 \%$ had secondary education with graduation, $34 \%$ of them had a college education and $18 \%$ had secondary education without graduation. In relation to the gender of the entrepreneur from total number of firms $75 \%$ of them were men and $25 \%$ of them were women.

In line with previous findings and taking in account the gender we have stated the following hypotheses:

H1: More than $60 \%$ of entrepreneurs said they regularly develop new products. There are statistically significant differences between men and women.

$\mathrm{H} 2$ : The innovative activities of the companies are severely limited due to the influence of the crisis. A maximum of $40 \%$ of entrepreneurs they have invested a lot of money into the development of new methods and technologies. There are statistically significant differences between men and women.

H3: A maximum of $20 \%$ of entrepreneurs agree with the statement that their firm has a reputation of aggressive company. There are statistically significant differences between men and women.

H4: A maximum of $20 \%$ of entrepreneurs agreed with the statement that often apply aggressive practices to the competition. There are statistically significant differences between men and women.

The associations in contingency tables were analyzed by Pearson statistics for data counting. Pvalue has been compared to standard 5\% confidence level. P-value that is lower than the confidence level leads to the adoption of our hypothesis. The calculations have been performed using software available at http://www.socscistatistics.com/tests. Statistically significant differences in the affirmative replies were analyzed through Z-score. Calculations were made by the free software available at http://www.socscistatistics.com/tests/ztest/Default2.aspx. Part of the quantitative analysis is the use of indicators and descriptive statistics such as the percentage figures.

\section{RESULTS AND SHORT DISCUSSION}

Table 1 presents the results of our research among entrepreneurs in the segment of SMEs. The following table sets out the views of male and female entrepreneurs. 
Table 1.The opinion of SMEs entrepreneurs in relation to regular development of new products and services in their firms

\begin{tabular}{|l|r|r|r|}
\hline $\begin{array}{l}\text { We regularly develop new products } \\
\text { and services in my company. }\end{array}$ & $\begin{array}{c}\text { men } \\
\text { in \% }\end{array}$ & $\begin{array}{c}\text { women } \\
\text { in \% }\end{array}$ & $\begin{array}{c}\text { p-value } \\
\text { Z-score }\end{array}$ \\
\hline 1. Fully agree & 9.99 & 13.57 & 0.0949 \\
\hline 2. Agree & 50.75 & 51.07 & 0.9283 \\
Share in \% (1+2) & 60.74 & 64.64 & $0.2420^{*}$ \\
Total share in \% (1+2)=61.70 & & 17.50 & 0.3421 \\
\hline 3. No position & 20.09 & 15.56 & 0.9522 \\
\hline 4. Disagree & 3.61 & 2.14 & 0.2301 \\
\hline 5. Completely disagree & & \\
\hline \multicolumn{2}{|l|}{} \\
\hline
\end{tabular}

(Source: own calculation).

Note: * means p-value of the Z-score calculated from the positive answers $(1+2)$

In our research we found that $61.70 \%$ of entrepreneurs regularly develop new products, which means that the first part of $\mathrm{H} 1$ was confirmed. The second part H1 was not confirmed. We found that there weren't statistically significant differences between men and women in the development of new products. So HI was partially confirmed.

Table 2 presents the results of the research in the field of investing money into new methods and technologies, and comparison between men and women.

Table 2.The opinion of SMEs entrepreneurs in relation to the investment into new methods and technologies

\begin{tabular}{|l|r|r|r|}
\hline $\begin{array}{l}\text { We invest a lot of money into the } \\
\text { development of new methods and } \\
\text { technologies }\end{array}$ & $\begin{array}{c}\text { men } \\
\text { in \% }\end{array}$ & \multicolumn{1}{c|}{$\begin{array}{l}\text { women } \\
\text { in \% }\end{array}$} & p-value \\
\hline 1. Fully agree & 4.76 & 6.43 & 0.2757 \\
\hline 2. Agree & 33.22 & 31.43 & 0.5823 \\
$\quad$ Share in \% $(1+2)$ & 37.96 & 37.86 & 0.9203 \\
Total share in \% (1+2)=37.60 & 25.55 & 27.86 & 0.4473 \\
\hline 3. No position & 30.89 & 29.64 & 0.6965 \\
\hline 4. Disagree & 5.58 & 4.64 & 0.5485 \\
\hline 5. Completely disagree & & \\
\hline
\end{tabular}

(Source: own calculation).

Our assumption that the innovative activities of the companies are severely limited due to the influence of the crisis was confirmed, because only $37.60 \%$ of entrepreneurs reported that they have invested a lot of money into the development of new methods and technologies. We found that there weren't statistically significant differences between men and women in this area. H2 was partially confirmed.

The most important business risks which were perceived by entrepreneurs in the Czech Republic in our previous research were as follows: market, financial and personnel risks. Market risk was 
identified as a key risk by the largest number of entrepreneurs $-79.44 \%$ of them in the Czech Republic (Belás et al., 2014 ). The situation is similar in Slovakia, where it was found out that the most important business risk was market risk (average value of perceived market risk was higher than 50\%). (Belás, Bilan, Ključnikov, Vincúrová, and Macháček, 2015)

The research results showed that men are slightly more innovative in developing new products and that both genders have the reserved attitudeto the financial investment in the development of new methods and technologies.

Our results in terms of innovativeness of men and women did not confirm the conclusions of DiazGarcia and Jimenez-Moreno (2010), Runyan et al. (2006), Ayub et al. (2013). Our research confirmed the findings byLim and Envick (2011).

In Table 3 sets out the views of entrepreneurs on whether their company is perceived as aggressive company.

\section{Table 3.The opinion of SMEs entrepreneurs in relation to the perception of their firms as an aggressive firm}

\begin{tabular}{|l|r|r|r|}
\hline $\begin{array}{l}\text { Our company has a reputation as an } \\
\text { aggressive company. }\end{array}$ & $\begin{array}{c}\text { men } \\
\text { in \% }\end{array}$ & \multicolumn{1}{|c|}{$\begin{array}{c}\text { women } \\
\text { in \% }\end{array}$} & \multicolumn{1}{c|}{-value } \\
\hline 1. Fully agree & 1.86 & 0.71 & 0.1835 \\
\hline 2. Agree & 9.87 & 6.43 & 0.0801 \\
Share in \% $(1+2)$ & 11.73 & 7.14 & 0.0300 \\
Total share in \% $(1+2)=10.60$ & & & 0.0357 \\
\hline 3.No position & 25.44 & 19.29 & 0.0466 \\
\hline 4.Disagree & 49.59 & 56.43 & 0.1031 \\
\hline 5.Completely disagree & 13.24 & 17.14 & $0.0010^{* *}$ \\
\hline Share in \% (4+5) & 62.83 & 73.57 & \\
\hline \multicolumn{2}{|r}{} \\
\hline
\end{tabular}

(Source: own calculation).

Note: ** means p-value for the answers $4+5$.

H3 was confirmed. We found that only $10.60 \%$ of all entrepreneurs agreed with the statement that their company has a reputation for aggressive company.

Values of the test criteria (chi square $=12.0600 / \mathrm{p}$-value $=0.0169$ ) confirmed that there are statistically significant differences in the overall responses of men compared to women. At the same time we found that there were statistically significant differences between men and women in the affirmative replies ( $p$-value $(1+2)=0.0300)$. Significantly more men-businessmen presented the view that the company has a reputation as an aggressive company. Women compared with men reported significantly more that their company does not have a reputation for aggressive firms ( $\mathrm{p}$ value $=0.0010)$

In Table 4 presents the results of the research on aggressive activities that are directed against competitors. 
Table 4.The opinion of SMEs entrepreneurs in relation to realizing aggressive activities against the competition

\begin{tabular}{|l|r|r|r|}
\hline $\begin{array}{l}\text { Our activities in relation to competition } \\
\text { are often aggressive. }\end{array}$ & $\begin{array}{c}\text { men } \\
\text { in \% }\end{array}$ & $\begin{array}{c}\text { women } \\
\text { in \% }\end{array}$ & \multicolumn{1}{c|}{ p-value } \\
\hline 1. Fully agree & 1.97 & 0.71 & 0.1527 \\
\hline 2. Agree & 11.50 & 9.64 & 0.3898 \\
Share in \% (1+2) & 13.47 & 10.36 & 0.1738 \\
Total share in \% (1+2)=12.71 & 20.67 & 15.71 & 0.0688 \\
\hline 3. No position & 55.52 & 59.29 & 0.2713 \\
\hline 4. Disagree & 10.34 & 14.65 & 0.0489 \\
\hline 5. Completely disagree & 65.86 & 73.94 & $0.0121^{* *}$ \\
\hline Share in \% (4+5) & $\chi^{2}=9.3148 / \mathrm{p}$-value $=0.0537$ \\
\hline
\end{tabular}

(Source:own calculation).

We found in our research that only $12.71 \%$ of all entrepreneurs reported that they used some aggressive practices against competition.

The values of the test criteria (chi square $=9.3148 / \mathrm{p}$-value $=0.0537$ ), which are on the borderline of acceptability confirmed that there are statistically significant differences in the overall responses of men compared to women. At the same time, we found that there were statistically significant differences in negative responses between males and females ( $p$-value $=0.0121$ ). Significantly more female entrepreneurs presented the view that their company does not use aggressive practices against competition. $H 4$ was confirmed.

Our results in the aggressiveness of men and women confirmed the findings by Goktan and Gupta (2015), Lim and Envick (2011), and Ayub et al. (2013).

According Blackburn, Hart, and Wainwright (2013) entrepreneurs with high risk tolerance, innovativeness and willingness to use new technologies are more successful in generating profits for the company (Laforet, 2013 presents similar conclusions presented in his study). They have also shown that, larger firms' growth rate is lower than the small firms' in terms of employee turnover and employment growth. The reason is that small firms are more flexible and when they find any new opportunity they hire new employees to penetrate the market. While controlling for sector differences, the results show that manufacturing firm's growth rate is lower than the service firms'. However, they find that when taking into consideration the size of the firm the innovative entrepreneurial firms outperform the other firms. More precisely, innovative entrepreneur perform 1.6 times better than other entrepreneurs. Finally, they find that, older firms, smaller in size, perform better than large firms in terms of profitability. It suggests that small firms are very careful about the growth and expansion of the business. They will expand the business, when they are much more certain that, they will have steady earnings from the expansion.

\section{CONCLUSION}

The results of our research have pointed out some differences between the genders. We could present our conclusions that men entrepreneurs doing business in the segment of SMEs in the Czech Republic are slightly more innovative and are significantly more aggressive in relation to competitors, because they apply more aggressive approach and their companies are perceived as aggressive. 
The results confirmed that both male and female entrepreneurs in the Czech Republic are trying to implement innovation policy in their companies. $60.74 \%$ of male respondents and $64.64 \%$ of women respondents are regularly developing new products and services in their companies, which is an important element of business orientation.

The research results have shown differences between men and women in the field of the aggressive business. Significantly more male entrepreneurs presented the view that their company has a reputation as an aggressive company. Women compared with men reported significantly more that their company does not have a reputation of aggressive company, and reported the opinion that their company did not use aggressive practices against competition more often.

Although it is clear that there are certain limits in our research (e. g. uneven representation of respondents by region and gender), we expect that our article has brought interesting findings and new incentives for further research, not only gender but also other socio-demographic factors influencing individual constructs of the entrepreneurial orientation.

In the future our research will concentrate on examination of other socio-demographic factors influencing the entrepreneurial orientation of SMEs in the Czech Republic.

\section{Acknowledgements}

The authors are thankful to the Internal Grant Agency of FaME TBU No. 000/IGA/FaME/2015: The possibilities of the financial performance growth for commercial banks in the context of the credit risk of SME and the customer satisfaction, for financial support to carry out this research.

\section{REFERENCES}

Anderson, B. S., Eshima, Y. (2013) The influence offirm age and intangible resources between entrepreneurial orientation and firm growth aminy Japanese SMEs. Journal of Business Venturing, 28(3): $413-429$.

Ayub, A., Razzaq, A., Aslam, M. S., Iftekhar, H. (2013) Gender effects on entrepreneurial orientation and value innovation: evidence from Pakistan. European Journal of Business and Social Sciences, 2(1): pp. 82 - 90.

Belás, J., Bilan, Y., Ključnikov, A., Vincúrová, Z., Macháček, J. (2015) Actual problems of business risk in segment SME. Case study from Slovakia. International Journal of Entrepreneurial Knowledge, 1(3): pp. 46-56.

Belás, J. et al. (2014) Business risks and the level of entrepreneurial optimism of SME in the Czech and Slovak Republic. Journal of Competitiveness, 6(2): $30-41$.

Blackburn, R. A., Hart, M., Wainwright, T. (2013) Small business performance: business, stratégy and owner-manager characteristics. Journa lof Small Business and Enterprise Development, 20(1): pp. $8-27$.

Boso, N., Story, V. M., Cadogan, J. W. (2013) Entrepreneurial orientation, market orientation, network ties, and performance: Study of entrepreneurial firms in a developing economy. Journal of Business Venturing,28: 708 - 727.

Boyer, T., Blazy, R. (2014) Born to bealive? The surfoval of innovative and noninnovative French micro-start-up. Small Business Economics, Vol. 42, pp. 669 - 683.

Brockman, B. K., Jones, M. A., Becherer, R. C. (2012) Customer Orientation and Performance in Small Firms: Examining the Moderating Influence of Risk-Taking, Innovativeness, and Oportunity Focus. Journal of Small Business Management, Vol. 50, pp. 429 - 446.

Diaz-Garcia, M. C. and Jimenez-Moreno, J. (2010) Entrepreneurialintention: the role of gender. International Entrepreneurship Management Journal, Vol. 6, pp. 261 - 283. 
Global Markets Institute. (2014) Giving credit where it is due. How closing the credit gap for women-owned SMEs can drive global growth. New York: Goldman Sachs International.

Goktan, A. B., Gupta, V. K. (2015) Sex, gender, and individua entrepreneurial orientation: evidence from four countries. International Entrepreneurship and Management Journal, Vol. 11, pp. 95 - 112.

Gudmundson, S. V., Lechner, C. (2014) Entrepreneurial orientation, firm strategy and small firm performance. International Small Business Research, 32(1): pp. $36-60$.

Hessels, J., Parker, S. C. (2013) Constraints, internationalization and growth: A crosscountry analysis of European SMEs. Journal of World Business, 48(1): pp. 137 - 148.

International Finance Corporation. (2013) Closing the Credit Gap for Formal and Informal Micro, Small, and Medium Enterprises. Pennsylvania Avenue, N.W.Washington, D.C. 20433. Available at:

http://www.ifc.org/wps/wcm/connect/4d6e6400416896c09494b79e78015671/Closing+the +Credi $\mathrm{t}+\mathrm{Gap}+$ Report-FinalLatest.pdf?MOD=AJPERES

Kessler, A. (2007) Success factors for new businesses in Austria and the Czech Republic. Entrepreneurship and Regional Development, Vol. 19, pp. $381-403$.

Kraus, S. (2013) The role of entrepreneurial orientation in service firms: empirical evidence from Austria. The Service Industrie Journal, 33(5): pp. 472 - 444.

Kozubíková, L., Bartoš, P. (2015). Personality Types of Entrepreneurs and Selected Attributes of Credit Risk in the SME Segment. A Case Study from Czech Republic and Slovakia. Proceedings of the 7th International Scientific Conference Finance and performance of firms in science, education and practise, Apríl 23-24, Zlín, Czech Republic, s. 728-737.

Kozubíková, L., Belás, J., Bilan, Y., Bartoš, P. (2015). Personal characteristics of entrepreneurs in the context of perception and management of business risk in the SME segment. Economics \& Sociology, Vol. 8, No1, pp. 41-54.

Laforet, S. (2013). Organizational innovative outcomes in SMEs: effects of size, age and sector. Journal of World Business, Vol. 48, pp. 490-502.

Langowitz, N., Minniti, M. (2007) Entrepreneurial propensity of women. Entrepreneurship Theory and Practice, 31(3): pp. $341-364$.

Lasagni, A. (2012) How Can External Relationships Enhance Innovation in SMEs? New Evidence for Europe. Journal of Small Business Management, Vol. 50, pp. 310 - 339.

Lim, S., Envick, E. R. (2011) Gender and Entrepreneurial Orientation: A Multi Country Study. International Entrepreneurship and Management Journal, Vol. 9, pp. 465 - 482.

Lumpkin, G. T., Dess, G. G. (1996) Clarifying the entrepreneurial orientation construct and linking it to performance. Academy of Management Review, 21(1): pp. 135 - 172.

Martínez-Román, J., Romero, I. (2013) About the determinants of the degrese of novelty in small businesses“ produkt innovations. International Entrepreneurship and Management, Vol. 9, pp. $655-677$.

Millian, J, M., Congregado, E., Roman, C., Van Praag, M., Van Stel, A. (2014) The Value of an Educated Population for an Individual's Entrepreneurship Success. Journal of Business Venturing, Vol. 29, pp. 312-632.

Moreno, N. M., Casillas, J. C. (2008) Entrepreneurial orientation and growth of SMEs: a casual model. Entrepreneurship Theory and Practice, 32(3): pp. 507 - 528.

Mueller, S., L., Dato-on, M. C. (2010) A cross-cultural study of gender-role orientation and its effect on entrepreneurial orientation. Proceedings of the 2010 USASBE Conference.

Runyan, C. R., Huddleston, P., Swinney, J. (2006) Entrepreneurial orientation and social capital as small firm strategies: a case study of gender differences from resources-based view, Entrepreneurship Management, Vol. 2, pp. 455 - 477.

Sidik, G. I. (2012) Conceptual framework of factors affecting SME development: Mediating factors on the relationship of entrepreneur traits and SME performance. Procedia Economics and Finance, Vol. 4, pp. 373 - 383. 
Soininen, J., Puumalaiene, K., Sjogren, H. and Syrja, P. (2012) The impact of global financial crisis on SMEs: Does entrepreneurial orientation matter? Management Research Review, 35(10): 927-944. 